\title{
Biology of the giant Tasmanian freshwater lobster Astacopsis gouldi (Clark) and its conservation
}

\author{
Todd S. Walsh and Bronwyn B. Walsh
}

\begin{abstract}
Astacopsis gouldi (Clark) is native to northern Tasmania, Australia. It is the world's largest freshwater crayfish, potentially attaining a weight of greater than $6 \mathrm{~kg}$ and a carapace length (CPL) in excess of $240 \mathrm{~mm}$. Field collection of $A$. gouldi and the recording of moulting events and growth have allowed an estimate of life history up to $3 \mathrm{~kg}$. The majority of $\boldsymbol{A}$. gouldi moult at least biennually, with the exception of the largest animals (over $5 \mathrm{~kg}$ ). The results of this study suggest that a $190 \mathrm{~mm}$ CPL $A$. gouldi male is approximately 20 years of age. The maximum size is estimated to be reached at 30-35 years of age. This paper examines the life history of the crayfish species and the issues and solutions to the decline in its populations.
\end{abstract}

\section{INTRODUCTION}

Astacopsis gouldi, commonly known as the giant freshwater lobster (Fig. 1), is the largest freshwater crustacean in the world, with recorded sizes of $76 \mathrm{~cm}$ and more than $3 \mathrm{~kg}$ (Hamr, 1990; Horwitz, 1991); recent surveys yielded a specimen over $4.5 \mathrm{~kg}$ (Walsh, 2006). Anecdotal and photographic evidence suggest that the species can reach a maximum size of greater than $6 \mathrm{~kg}$ and a total outstretched length of more than one metre. Large males can have chelae (claws) that are as large as a man's hand, and are capable of breaking and crushing bone.

\section{Geographic range}

This species is endemic to northern Tasmania, Australia. Its recorded distribution ranges from the Arthur-Pieman catchment in North-West Tasmania, across the northern part of the state between $20-400 \mathrm{~m}$ above sea level in most river systems discharging into Bass Strait (see Fig. 2), but today the distribution is more broken (Inland Fisheries Service, 2008).

It has been introduced into two catchments outside its natural range: the North Esk catchment (St Patrick's River) and the Derwent catchment (Clyde River) (Threatened Species Section, 2006). Excluding these the estimated extent of occurrence (EOO) of this species is estimated at $14,221 \mathrm{~km} 2$ (Walsh \& Nash, 2002).

Approximately $54 \%$ of the species' range occurs on unreserved private land, $24 \%$ on state forest, and $2 \%$ on other public land (e.g. unallocated Crown land, local council, etc). Approximately $19 \%$ of the species' range lies in either formal or informal reserves (Threatened Species Section, 2006). It must be noted that the majority of this range held privately has been extensively modified. The best remaining habitat for this species is

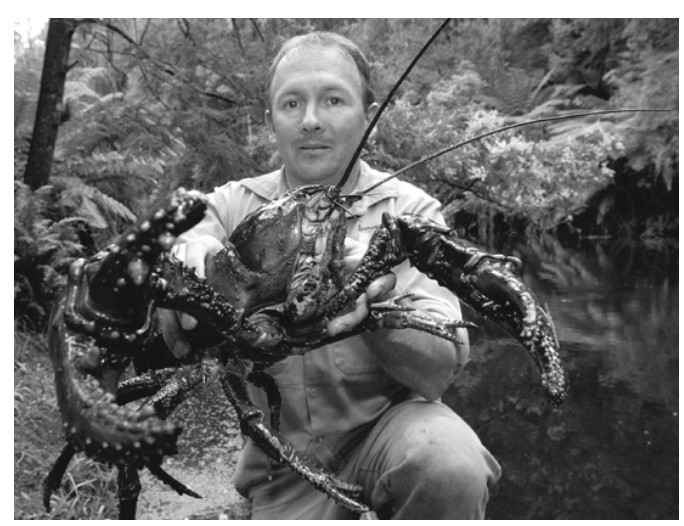

Fig. 1. The author holding a $4.5 \mathrm{~kg}$ specimen in 2008 . 


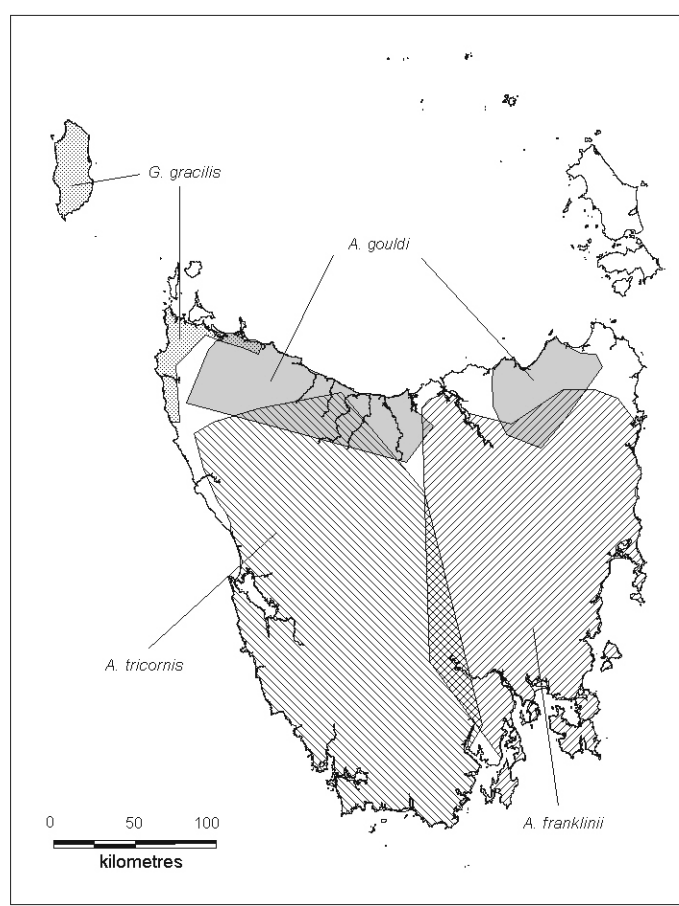

Fig. 2. Distribution map for Astacopsis species (from Richardson et al., 2006).

located in state forest and crown land.

Two other species of Astacopsis are recognized (Hamr, 1990): A. franklinii and A. tricornis. These are smaller species, and have different distributions to $A$. gouldi (less than $5 \mathrm{~kg}$ ), although there is some overlap for all three species' distributions (Fig. 2). A. franklinii may also be found in the NorthEast of Tasmania, and due to similar habitat requirements may also be found in sympatry with A. gouldi (Richardson et al., 2006).

\section{Habitat}

Astacopsis gouldi can be found in rivers and streams of all sizes (summary of essential habitat assessment criteria is shown at end of present paper), but shows a preference for undisturbed habitats. Habitat requirements for Astacopsis gouldi may vary, depending on the age class. Adults are most commonly found sheltering under decaying logs and undercut banks within deep pools, but can also be seen moving through shallow riffle zones (Hamr, 1990; Inland Fisheries

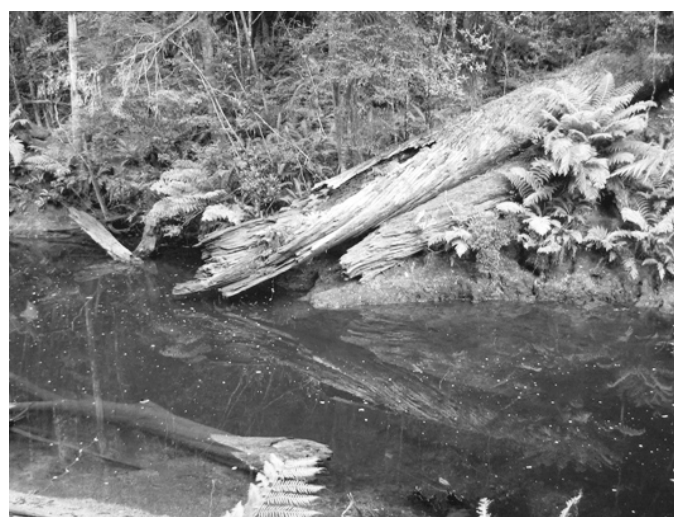

Fig. 3. River habitat of $A$. gouldi.

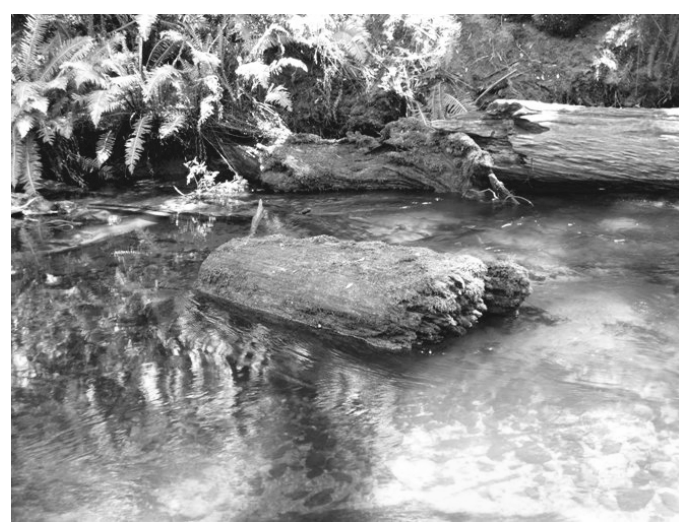

Fig. 4. Juvenile $A$. gouldi habitat.

Service, 2008) and along small tributaries and even on dry land (T. Walsh, unpublished data). Adults often dig burrows in stream banks and underneath logs and boulders in the streambed (Lynch \& Bluhdorn, 1997). Complicated burrows have been observed, in one case up to 10 lobsters were found residing in a $10 \mathrm{~m}$ stretch of riverbank wall ( $\mathrm{T}$ Walsh unpublished data). Juveniles, approx. 10-75 $\mathrm{mm}$ Carapace Length (CPL), require shallow, fast-flowing streams with substrates containing primarily cobbles and boulders that are used for shelter. The sheltering rocks and sometimes logs also provide a food resource (may be somewhat "biological film"), which removes the risk of foraging in the open water where predators may be found. As a general rule, 


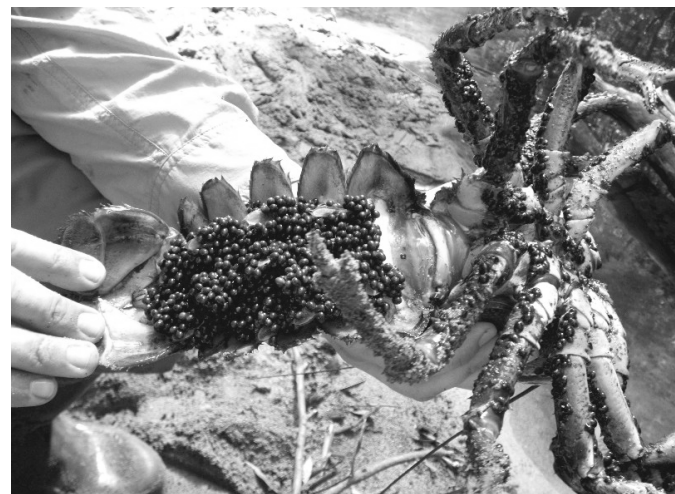

Fig. 5. A female with eggs.

A. gouldi requires well-vegetated forest streams (weed bed and riparian) with low turbidity and even temperatures, based on Giant Freshwater Lobster Fact Sheet, Threatened Species Unit, Parks and Wildlife Service (Threatened Species Section, 2006). Abundant in-stream and riparian vegetation provides both food and habitat for A. gouldi; it also protects the water from temperature extremes and often acts as a filtration system, reducing the turbidity level of the water (Lynch \& Bluhdorn, 1997). In-stream woody debris is of particular importance to A. gouldi (Hamr, 1990), and is usually considered a critical habitat requirement; $A$. gouldi primarily eats woody debris and leaf litter (Lynch, 1967; Hamr, 1990; Walsh, unpublished data) and large logs provide the bulk of in-stream structures that $A$. gouldi uses for shelter (Hamr, 1990; Lynch \& Bluhdorn, 1997; Walsh, unpublished data). This species displays a shift in dietary preferences with age but it typically feeds on decaying wood, rotting flesh, and small fish. Juvenile $A$. gouldi may have a higher animal content in their diet, due to the relative size of the prey and its abundance in the riffle zone, particularly in waterways with minimal human impact. Presence of relatively undisturbed riparian vegetation is therefore another important factor determining the distribution of this species. Juvenile densities of this species are higher in wider streams at intermediate catchment sizes (typically 2 to $30 \mathrm{~km}^{2}$ ), streams with low levels of silt substrate $(0-2 \%)$, streams

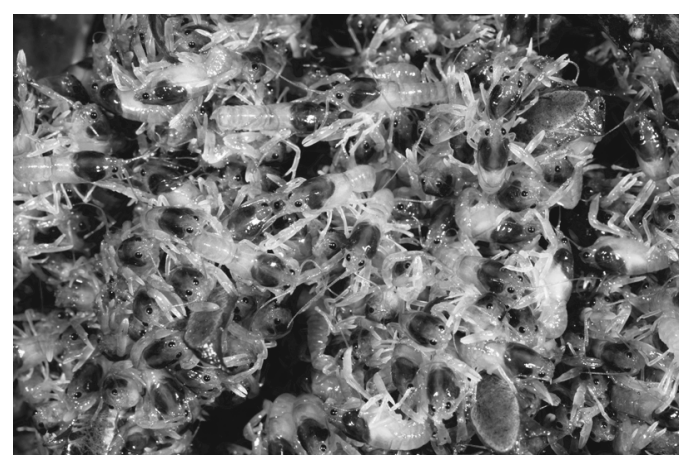

Fig. 6. Juvenile A. gouldi under mothers' tail.

with high proportions of moss cover $(10 \%$ and above), and with higher proportions of boulder substrate (Davies \& Cook, 2004). These specific habitat requirements could have severe consequences for recruitment if altered, since even though adult females are producing eggs, no juveniles may survive due to poor habitat quality, resulting in reduced, or no, recruitment, until habitat conditions are improved (T. Walsh, unpublished data).

In-stream sediment has a significant influence on populations (Walsh \& Nash, 2002), and areas which have large amounts or increased levels of sedimentation are avoided by this species ( $T$. Walsh, unpublished data). High sediment levels affect $A$. gould $i$ populations in various ways. High sediment levels fill in the spaces between cobbles and boulders, removing vital shelter and feeding places for juveniles and forcing them into open water where predation is a risk. The removal of juvenile habitat and the resulting lack of recruitment over years, even decades, can slowly eradicate whole cohorts from kilometers of waterway. Sites which had been completely cleared of riparian vegetation to create agricultural land etc. showed an absence of this species (Hamr, 1996; Horwitz, 1994). While the presence of native riparian vegetation is important to this species, it has also been occasionally found within plantations of non-native pines (Threatened Species Section, 2006). In terms of water chemistry, there is a noted preference for sites with a high oxygen content and little suspended 


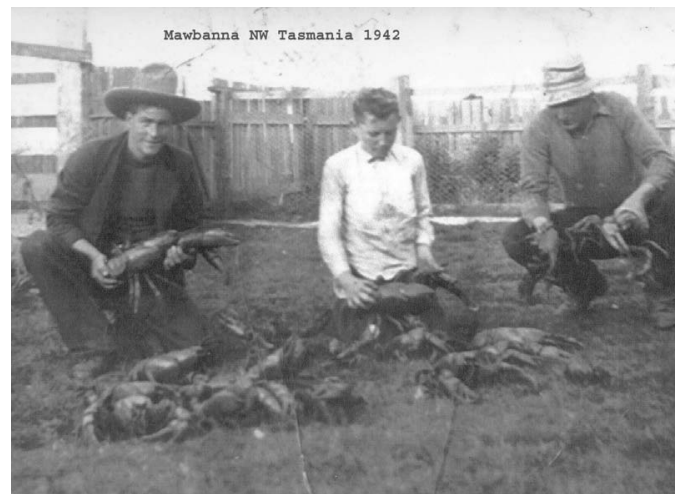

Fig. 7. One days' fishing in Mawbanna in 1942.

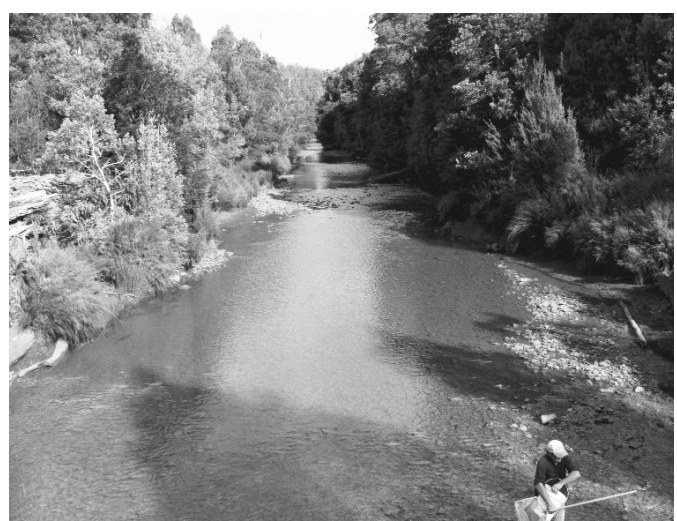

Fig. 9. Ferrous deposits and colouring of river substrate.

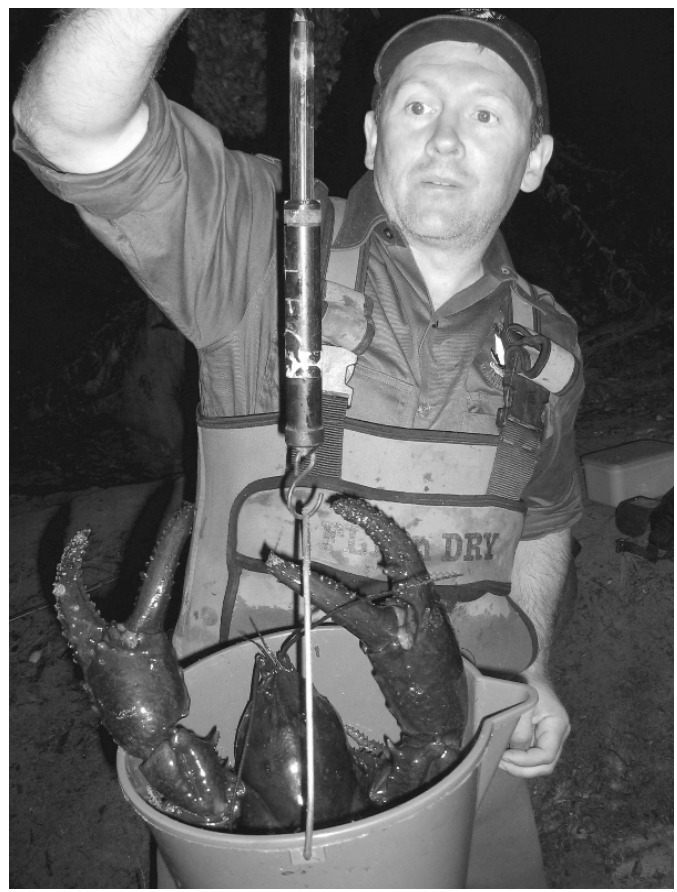

Fig.12. Measuring a young adult.

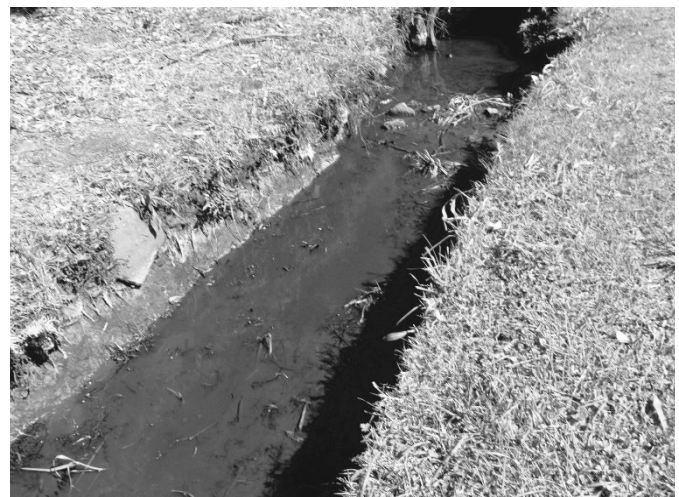

Fig. 8. A modified creek with heavy siltation.

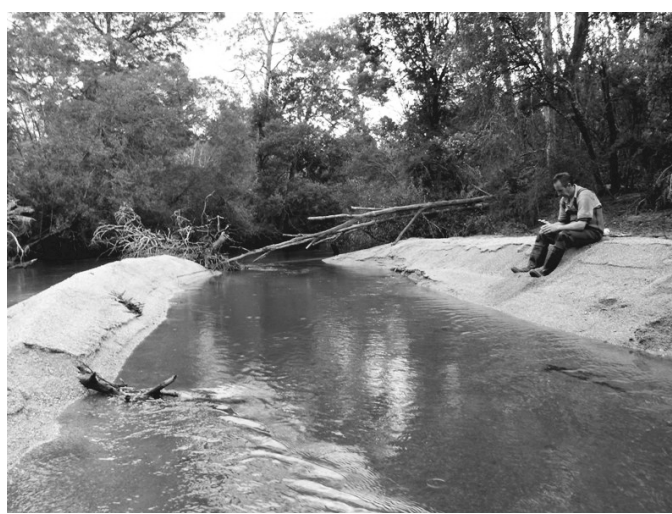

Fig. 10. Silt deposits Great Forester River.

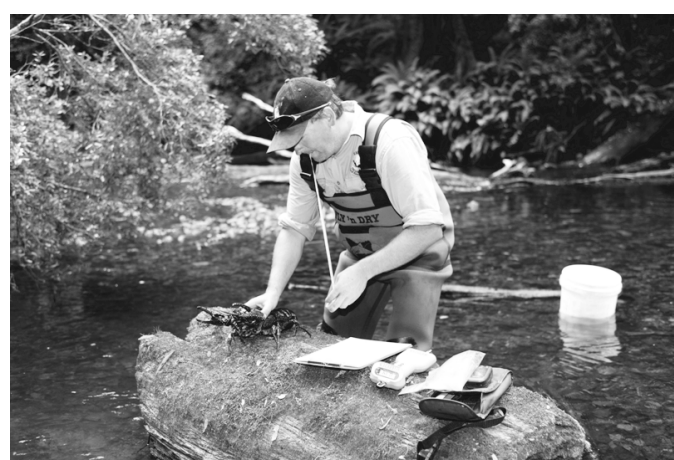

Fig. 11. Weighing a large male. 
sediment (Forteath, 1987). This species has been found through a range of water temperatures from $5.2{ }^{\circ} \mathrm{C}$ to $21{ }^{\circ} \mathrm{C}$ (Hamr, 1990; Lynch \& Blühdorn, 1997; Webb, 2001), although relatively low temperatures are preferred (Threatened Species Section, 2006). Davies (2004) states that $A$. gould $i$ prefers water temperatures of less than $18{ }^{\circ} \mathrm{C}$ and oxygen levels greater than $7 \mathrm{mg} / \mathrm{L}$, and notes that they are sensitive to sedimentation. Davies \& Cook (2004) give an approximate threshold value of $5 \%$ silt substrate and salinity threshold of $160 \mathrm{microSiemens} / \mathrm{cm}$ (no A. gouldi were captured these conditions during their surveys). These are important factors to consider when evaluating both the likelihood of $A$. gouldi being present at any given site within its distribution, and also when considering the potential impacts that any development may have on these values.

This species displays a high degree of site fidelity. Studies in which mark and re-capture techniques have been applied, tracked this species moving distances of 500 m (Forteath, 1987; Growns, 1995) and 1650 m. (Webb, 2001). But Webb (2001) also noted that the animals returned to their home site in the stream after movement. Recent studies (T. Walsh, unpublished data) have shown that adults reside in a similar stretch of stream for at least a $7-8$ year period, and more probably for life once they reach adulthood.

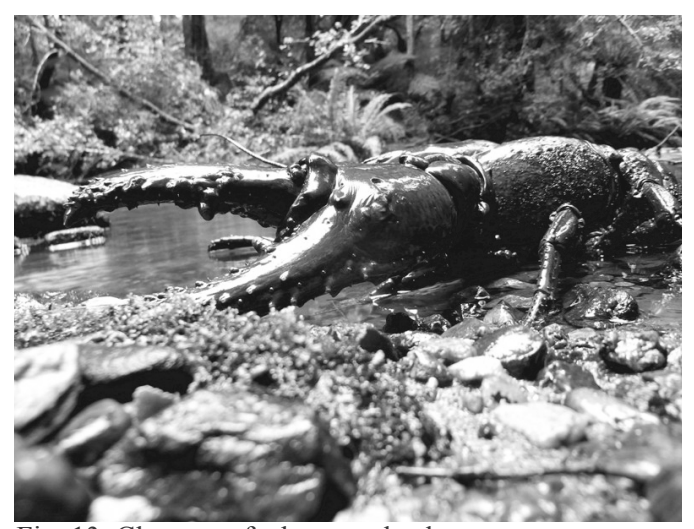

Fig. 13. Close up of a large male claw.

\section{Life history}

Mating and spawning typically occur in the autumn months' after the summer molt, with females assumed to be breeding every two years (Hamr, 1990, 1992). However, recent studies have shown that females can release young and moult in the same year, meaning that they can potentially breed each year (Threatened Species Section, 2006; Inland Fisheries Service, 2008). Juveniles remain attached to the mother until February and are released in late summer (T. Walsh personal observation), and the number of eggs produced by female increases with body size (Hamr, 1996).

Males reach sexual maturity at approximately nine years (Hamr, 1996).

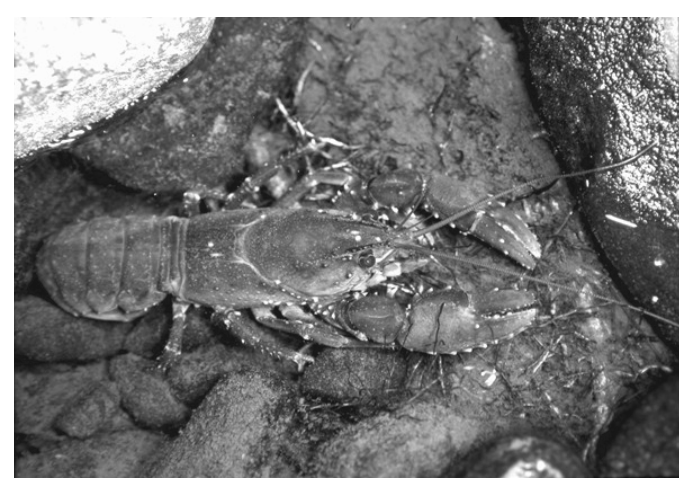

Fig. 15. Astacopsis franklinii (from Niall Doran)
Fig. 14. Astacopsis tricornis (from Inland Fisheries Service, Tasmania, 2008) 
Juveniles remain in the riffle zone for up to seven years, and then reside as sub-adults for another seven years in areas that link deeper pools, sometimes migrating through the deeper pools (T. Walsh personal observation). When fully adult, they tend to reside mostly in the deeper areas with sufficient cover for protection from other lobsters and larger predators such as predatory such as larger birds of prey and water rats.

Courtship involves the males stroking the females with their antennae and chelae (claws) and presenting the chelae and tail alternately to the female. Courtship can take days, even weeks before mating (Hamr, 1992b). The male appears to flip the female onto her back and then proceed to mount. The ventral thoracic surfaces then touch. The male deposits sperm just behind the female gonopore. The sperm is encased in a protective gel which dissolves in water, allowing fertilization to occur. The female extrudes the fertilized eggs from the gonopore to beneath the tail, which has formed a cup under the gonopore. The eggs attach to the pleopods, where they remain for nine months before hatching (Hamr, 1992b), usually around late December. The young moult three times while still under the mother's tail. At the fourth moult (approximately six weeks after hatching, mid February) the young venture into the riffle zone and begin living on their own.

\section{Population}

Based on condition of habitat, historical records and anecdotal reports, localized extinctions or large declines in numbers are thought to have occurred in the Welcome, Montagu, Rubicon, Don, Brid, Boobyalla, Pipers, Ringarooma, Duck, Little and Great Forester Rivers and Claytons Rivulet (Horwitz, 1994).

Recent surveys in the eastern section of this species' range indicated that massive population declines have occurred in these north-east catchments (Little Forester, Boobyalla-Tomahawk and Ringarooma) and major population declines have occurred in Pipers and Great Forester / Brid catchments (T. Walsh, unpublished data). Just two small areas within these two catchments appear to have stable populations (T. Walsh, unpublished data). These north-eastern populations have been badly fragmented and are subject to substantial pressures such as broad scale plantation establishment and severe drying of streams (N. Doran, personal communication). This reduction of populations in the north-eastern range may equate to approximately one third of the total for this species. Recovery is, however, occurring in the north-west of the state $(\mathrm{N}$. Doran, personal communication). There, regularly monitored sites in the northwest catchments have shown an increase in average and maximum size in the last 5 years (T. Walsh unpublished data). The total closure of any recreational fishing has contributed to the increase of the population size and structure. Fishing was a regular recreational pursuit within the lobster's range, and at least 10,000 individuals were taken annually, however the figure is estimated to be quite likely up to 100,000 (T. Walsh, unpublished data).

At sites that are relatively accessible to humans (close to roads), the proportion of mature individuals in a population can be as low as $5 \%$ compared to $40 \%$ in relatively inaccessible sites (Hamr, 1990). The authors estimate that there has been more than an $80 \%$ decline in this species abundance in the last 50 years, and has undergone a dramatic decline in $70 \%$ of its range. However, it has also been suggested that there may have been increased in population abundance in catchment areas with relatively good habitat conditions, namely (from West to East) Black- Detention, Inglis, Cam, Emu, Blythe and Leven (T. Walsh, unpublished data).

\section{Threats}

The most significant threats facing this species are past fishing pressure, present illegal fishing, and habitat loss and degradation (Lynch, 1967; Hamr, 1990; Horwitz, 1994; Growns, 1995; Lynch \& Blühdorn, 1997). Under the Inland Fisheries Act 1995, the legal fishing of this species ceased as of January 1st 1998. While the relationship between fishing pressure and population dynamics and structure is not fully understood, decreases in average 
body size and the proportion of mature individuals present at accessible sites compared to inaccessible sites probably indicate the negative impact that intense fishing pressure has had upon the population (Lynch \& Blühdorn, 1997; Hamr, 1990). Of note is the negative effect of removing larger males which are the only individuals that can, because of their size, mate with large mature females ( $\mathrm{T}$. Walsh, unpublished data). However, since the fishing ban has been imposed, a significant increase in size has been observed in the population ( $\mathrm{T}$. Walsh unpublished data). The effects of fishing pressure on this species are further exacerbated by the slow maturation, low fecundity and biennial breeding cycle of this species. Furthermore, the authors suggest that it would take at least 15 years for juveniles to attain a size where the recruitment levels start to increase significantly after the termination of fishing. Despite the law forbidding the legal harvesting, illegal fishing activity is still occurring throughout this species' range as evidenced by baitlines, anecdotal reports and prosecutions (Threatened Species Section, 2006). Although fishing pressure has decreased considerably, due to this species' large size it is easy to catch and major damage can be inflicted a few poachers in a relatively short space of time.

Habitat loss and degradation is also a significant threat to this species. Due to its preference for relatively undisturbed sites, changes in land use and alterations to the hydrological regime of a river system are all likely to impact this species. It is the authors' opinion that logging now poses a greater risk to this species than illegal fishing. Large-scale, industrial logging activity throughout Tasmania has been implicated in sedimentation of waterways through the loss of sediment stability, resulting in increased turbidity and lower dissolved oxygen concentrations, thus creating unfavorable habitat for juveniles (Davies \& Cook, 2004). Loss of riparian zones can also result in increased run-off from surrounding land, decreased shading resulting in increased water temperatures, and decreased rotting vegetation provide an important food source. Other threats associated with forestry activities include chemical spraying and the conservation of loading and stream culverts: the latter present a barrier to effective dispersal.

Parts of the north-west region of this species' range are heavily impacted by agriculture and industry, especially in areas below $200 \mathrm{~m}$ altitude. We estimate that the population of this species has been extirpated for up to $20 \mathrm{~km}$ of the upper reaches of the Arthur River, due to heavy metals still flushing from a tin mine. A large creek pours from the mine into the river with a $\mathrm{pH}$ of less than 3 (T. Walsh unpublished water quality data 2004-2011). The giant freshwater lobster is also potentially impacted by the effects of climate change as increased aridity causes streams to dry up and as farmers increase water extraction for irrigation, especially in the north-eastern region which has hotter, drier summers (T. Walsh, unpublished data).

There is very little area remaining in the north-east which could still be classified as suitable $A$. gouldi habitat. Many waterways are heavily degraded, with little or no riparian zone and major sedimentation issues. There has been a long history of mining in the area, with the waterways used as dumping grounds for tailings etc. There is also a long history of land clearing for other purposes (agriculture, forestry), which has also introduced heavy loads of sediment to many waterways. Unfortunately, the soil properties in the northeast (soils are readily eroded, and predominantly composed of gravel and sand in many areas) contribute to the sedimentation issues that plague this region. Huge "slugs" of sediment, which can be many kilometers in length, are slowly making their way to the estuaries. The "slugs" predominantly consist of gravel and sand, which tend to fill in pre-existing deep pools and cover the logs, and the cobble and boulder substrate, which juveniles use.

Agriculture, as well as native and introduced tree plantations cover much of the remaining original range of $A$. gouldi. Sedimentation and lack of native riparian zones have contributed to the lack of suitable areas in which significant populations could be found. Habitat in many larger waterways is fragmented; there may be small 
populations in some of these fragments, but they will always be disjunctive populations with significant habitat issues both upstream and downstream.

\section{Conservation}

The giant freshwater lobster has received much attention as a species of conservation concern. In 1995 it was listed as Vulnerable under 1) the Commonwealth of Australia, Environment Protection, 2) Headquarters Road Dam - Environmental Flows Assessment, March 2004 Report to DPIWE Water Management and Planning Branch, and Biodiversity Conservation Act, 1999 (and preceding legislation) (Davies, 2004), and 3) the Tasmanian Threatened Species Protection Act 1995. Under the Tasmanian regional assessment process (Tasmanian Threatened Species Protection Act, 1995), it was identified as a "Category Three" fauna species i.e. requiring conservation through management plans (PLUC, 1997). It was then subsequently listed as a 'priority species requiring consideration' under the Tasmanian Regional Forest Agreement 1997 and thereby protected through the Comprehensive, Adequate and Representative (CAR) Reserve System. However, after 11 years there has not been one area specifically reserved for this species, even though there have been at least three reports, documenting the stable population areas remaining ( $\mathrm{T}$. Walsh, unpublished data). The authors have calculated that 30,000 ha would be sufficient to protect the best remaining tracts of habitat.

Management of this species is primarily governed by the Threatened Species Unit (Tasmania Department), which introduced the ban upon the harvesting, trade or keeping of this species without a permit since the 1 st of January 1998.

The Tasmanian Giant Freshwater Lobster Recovery Plan has an attachment describing what can be classified as suitable habitat, though only below $250 \mathrm{~m}$ above sea level. However, most forest operations occur above $250 \mathrm{~m}$, as below this altitude the forests have predominately been cleared (T. Walsh unpublished data). Furthermore, stream classification will require to protect the diverse habitats of the freshwater giant lobster, small streams are not protected by buffer zones and headwater areas are not given buffers, because not many lobsters are located in there (T. Walsh, unpublished data).

Recovery is primarily occurring in the northwest of Tasmania, while populations in the northeast appear to have been too badly fragmented and subject to substantial pressures: (i.e. broadscale plantation establishment and severe drying of streams) to show any significant improvement (N. Doran personal communication).

In response to the widespread dramatic declines seen in this species' population abundance, a recovery plan of conservationists in Tasmania has been developed to see the species down listed from 'Vulnerable' within the next 14 years (one generation). The following strategies have been proposed: 1) reduction in fishing pressure, 2) prevention and amelioration of the effects of habitat disturbance, 3) monitoring of population recovery, and identification and protection of core populations, 4) increasing knowledge of the species' biology and habitat requirements and 5) overall coordination of the recovery process. Integration of local communities within the recovery strategies is going to be necessary, to ensure the success of the project (Threatened Species Section, 2006). Protection and rehabilitation of riparian buffer strips adjacent to high habitat suitability sites (as defined by Davies \& Cook, 2004) is imperative to ensure the continued viability of these populations.

One of the authors (TSW) has carried out a program of population surveying under various auspices since 1998. Lobsters are captured, weighed, measured, tagged and released at the point of capture. A large database of almost 2000 specimens at more than 100 sites has been catalogued to date. Data from these surveys have gone a long way to understanding the life history of this species, and therefore offer vital information to assist in the long term viability of the worlds' largest freshwater crustacean.

Acknowledgements.-We would like to thank: Premek Hamr, Alastair Richardson, and Niall Doran for their crayfish expertise. 
Sue Botting, Alison Dugand and the Cradle Coast Authority Natural Resource Management for their ongoing support. Thanks also to Phil Bell, Sally Bryant and the Threatened Species Unit, and the Inland Fisheries Service for providing permits and assistance and to Kent Walsh for all the field assistance.

\section{LITERATURE CITED}

Commonwealth Environment Protection and Biodiversity Conservation Act, 1999

Davies, P., 2004. Headquarters Road DamEnvironmental Flows Assessment, March 2004 Report to DPIWE Water Management and Planning Branch.

Davies, P., \& Cook, L., 2004. Juvenile Astacopsis gouldi in headwater streamsrelative abundance and habitat. Report to the Forest Practices Board.

Forteath, N., 1987. The aquaculture potential of the giant freshwater crayfish Astacopsis gouldi. School of Applied Science, Tasmanian State Institute of Technology, Launceston.

Growns, I.O., 1995. Astacopsis gouldi in streams of the Gog Range, northern Tasmania: the effects of catchment disturbance. Proceedings of the Royal Society of Tasmania, 129: 1-6.

Hamr, P., 1990. Comparative reproductive biology of the Tasmanian freshwater crayfishes Astacopsis gouldi (Clark) Astacopsis frankilinii (Grey) and Parastacoides tasmanicus (Clark). Ph.D. thesis. Zoology Department, University of Tasmania.

Hamr, P., 1992b. Embryonic and postembryonic development in the Tasmanian freshwater crayfishes Astacopsis gouldi, Astacopsis franklinii and Parastacoides tasmanicus tasmanicus (Decapoda: Parastacidae). Australian Journal of Marine and Freshwater Research, 43: 861-878.

Hamr, P., 1997. A giant's tale: the life history of Astacopsis gouldi (Decapoda: Parastacidae). Freshwater Crayfish, 11: 13-33.

Horwitz, P., (1991). On the distribution and exploitation of the Tasmanian giant freshwater lobster Astacopsis gouldi Clark. Centre for Environmental Studies, University of Tasmania. Report to the Office of the National Estate.

Horwitz, P., 1994. Distribution and conservation status of the Tasmanian giant freshwater lobster Astacopsis gouldi (Decapoda: Parastacidae). Biological Conservation, 69: 199-206.

Inland Fisheries Service, 2008. Fact Sheet for giant freshwater lobster. Available online at: http://www.ifs.tas.gov.au/ifs/ IFSDatabaseManager/SpeciesDatabase/ giant-freshwater-lobster. (Accessed: July).

Lynch, D. D., 1967. A synopsis of biological data of the giant freshwater crayfish Astacopsis gouldi Clark 1936. Inland Fisheries Commission, Hobart.

Lynch T. P., \& Bluhdorn, D. R., 1997. Reservation assessment and habitat requirements of the giant freshwater lobster, Astacopsis gouldi. Report to the Tasmanian RFA Environment and Heritage Technical Committee.

Richardson, A., Doran, N., \& Hansen, B., 2006. The geographic ranges of Tasmanian crayfish: extent and pattern. Freshwater Crayfish, 15: 1-17.

Threatened Species Section, 2006. Giant freshwater lobster Astacopsis gouldi recovery plan 2006-2010. Department of Primary Industries and Water, Hobart.

Walsh, T., \& Nash, W., 2002. Factors influencing the health of the giant freshwater lobster in Tasmanian rivers. Report of Inland Fisheries Service, Hobart.

Walsh, T., 2006a. Lobster ID 861 (DIP022). In Microsoft Access database recording all Astacopsis gouldi captures by Todd Walsh 1998-current, annually reported to Threatened Species Unit, DPIW.

Webb, M., 2001. Movement patterns and habitat use of adult Astacopsis gouldi in the Dip River, North-West Tasmania. Honors thesis, School of Zoology, University of Tasmania.

Appendix: Summary of Essential Habitat Asessment Criteria 
In stream habitat:

Shelter must be available; adults require woody debris, undercut banks or boulders for habitat. One of these must be present.

Absence of sediment, which fills in all available pools and undercut banks severely restricts habitat availability for adults and juveniles.

\section{Substrate:}

Predominantly cobble substrate or larger.

Riffle areas must be relatively sediment free ( $<5 \%$ silt for juveniles).

Other fine sediments such as sand, gravel and pebble appear to be unsuitable for juvenile $A$. gouldi and can not be the largest available substrate.

\section{Water Quality:}

High in oxygen content, temperature range $4-21^{\circ} \mathrm{C}$,

Electrical conductivity $<500$ microsiemens

Low turbidity after rainfall events to prevent sedimentation.

Riparian zone and canopy:

Riparian zone predominantly trees with closed canopy (especially smaller tributaries), shading important for temperature regime.

Riparian zone must have ability to supply waterway with in-stream woody debris and plant material for food. Trees provide a good food source and habitat.

Riparian grassland, tea tree and scrub do not appear to provide suitable habitat for $A$. gouldi.

Complete assessment criteria may be accessed at: AusRivas criteria http://ausrivas. canberra.edu.au/

Addresses: (TSW, BBW) Kanunnah Pty Ltd85 Lovett St, Ulverstone, Tasmania, Australia ;

Email: (TSW, BBW) giantlobsters@ hotmail.com 